NBER WORKING PAPER SERIES

\title{
PRODUCTIVITY GROWTH AND WORKERS' JOB TRANSITIONS: EVIDENCE FROM CENSAL MICRODATA
}

\author{
Elias Albagli \\ Mario Canales \\ Chad Syverson \\ Matias Tapia \\ Juan Wlasiuk \\ Working Paper 28657 \\ http://www.nber.org/papers/w28657 \\ NATIONAL BUREAU OF ECONOMIC RESEARCH \\ 1050 Massachusetts Avenue \\ Cambridge, MA 02138 \\ April 2021, Revised March 2022
}

We thank Fernando Alvarez, Andres Fernandez, Andreas Mueller, Richard Rogerson, Isaac Sorkin and seminar participants at the Central Bank of Chile Workshop on Labor Markets and Productivity and the V Santiago Macroeconomics Workshop for useful comments and suggestions. Alvaro Castillo provided excellent research assistance. The views expressed in this paper are exclusively those of the authors and do not necessarily reflect the position of the Central Bank of Chile or its Board members. Any errors or omissions are responsibility of the authors. The views expressed herein are those of the authors and do not necessarily reflect the views of the National Bureau of Economic Research.

NBER working papers are circulated for discussion and comment purposes. They have not been peer-reviewed or been subject to the review by the NBER Board of Directors that accompanies official NBER publications.

(C) 2021 by Elias Albagli, Mario Canales, Chad Syverson, Matias Tapia, and Juan Wlasiuk. All rights reserved. Short sections of text, not to exceed two paragraphs, may be quoted without explicit permission provided that full credit, including $\odot$ notice, is given to the source. 
Productivity Growth and Workers' Job Transitions: Evidence from Censal Microdata Elias Albagli, Mario Canales, Chad Syverson, Matias Tapia, and Juan Wlasiuk

NBER Working Paper No. 28657

April 2021, Revised March 2022

JEL No. D2,E23,J2,J6,L11

\begin{abstract}
$\underline{\text { ABSTRACT }}$
A large body of work has highlighted the importance of employment reallocation as a driver of aggregate productivity growth, but there is little direct evidence on the extent of this process at the firm-worker level. We use an administrative matched employer-employee census for Chile to provide novel insights into the relationship between job transitions and productivity variation across firms, and to quantify the contribution of different worker groups to aggregate reallocation. As many theories would predict, worker flows from lower- to higher-productivity firms are larger than those of the opposite sign. Empirically, however, this is only marginally so. Almost half of all transitions occur "down the firm productivity ladder." This process is also highly heterogeneous along several dimensions. Up-the-ladder flows are more likely for direct job-to-job transitions than those that pass through non-employment, and among firms in the upper end of the productivity distribution. They are also much more likely for young, high-skilled workers, whose job transitions comprise in an accounting sense the lion's share of aggregate productivity change. Interestingly, workers with the highest job turnover rates contribute proportionally the least to aggregate productivity changes. Aggregate reallocation gains are therefore mostly explained by a relatively narrow subset of job transitions. Put together, this evidence implies that the productivity mechanics of job reallocation yield a net benefit, but this hides massive and heterogeneous gross flows underneath.
\end{abstract}

Elias Albagli

Central Bank of Chile

Monetary Policy Division

ealbagli@bcentral.cl

Mario Canales

Central Bank of Chile

mcanales@bcentral.cl

Chad Syverson

University of Chicago

Booth School of Business

5807 S. Woodlawn Ave.

Chicago, IL 60637

and NBER

chad.syverson@chicagobooth.edu
Matias Tapia

Central Bank of Chile

mtapia@bcentral.cl

Juan Wlasiuk

Central Bank of Chile

Agustinas 1180

Santiago, RM 6500590

Chile

jwlasiuk@bcentral.cl 


\section{Motivation}

Labor markets reallocate workers across firms and sectors over time. The ease with which such reallocation responds to shifts in supply and demand primitives at the micro level has considerable influence on businesses' and industries' trajectories, frictional unemployment, and, over longer horizons, aggregate productivity growth. On this last point, a large body of work suggests that reallocation of labor and other factors works in the "right direction" - that is, workers move away from firms with lower marginal products and toward those with higher marginal products. In aggregate, this process explains a relevant share of an economy's productivity gains.

At the same time, however, substantial differences in measured productivity across firms persist over time, suggesting that frictions limit the speed and completeness of productivity-enhancing reallocation.

In this paper we seek to make headway in understanding empirically how labor market reallocation interacts with the presence of heterogeneous-productivity firms, and quantify the sources of aggregate productivity growth associated with labor reallocation.

Our investigation leverages a matched employer-employee census for Chile spanning 2005 to 2016. Chile is an interesting case study in labor reallocation dynamics for several reasons. It is a small open economy with substantial exposure to relative price shocks, particularly in commodities. This, alongside the influence of technological change, leads to a significant amount of labor reallocation across firms and sectors. In fact, Chile ranks highest among OECD countries in terms of labor turnover, with large firm-level job creation and destruction rates and short employment spells for individual workers (Albagli et al., 2017). At the same time, as in many other countries, there is a large degree of persistent measured misallocation across Chilean firms, pointing to sizeable potential productivity gains through employment reallocation (Busso et al., 2013; Bergoeing et al., 2010). This poses a puzzle directly tied to our core question: if the labor market is so fluid, why are productivity differentials across firms so persistent? Do individual job transitions actually correlate with productivity differentials?

Our data allow us to track individual workers' job histories at monthly frequency and to compute annual firm-level productivity measures across all economic sectors. This enables a detailed look at how productivity gaps across firms relate to worker flows among them, as well as a direct quantification of the relative contributions of different worker groups to aggregate productivity gains from reallocation.

We highlight three results. First, while on average individual job transitions move workers from lower-productivity to higher-productivity firms, the fraction of all job changes that flow up the productivity ladder is only marginally higher than those in the opposite direction. Almost half ( $48 \%$ in our preferred specification) of all job changes move workers towards firms that have lower productivity levels than their prior employer. Thus, results on net labor reallocation towards higher-productivity firms hide a very large degree of job churning whose productivity implications mostly cancel.

Our next two results show that, despite overall job reallocation flows looking almost 
random, a more detailed analysis indicates that they exhibit more definite patterns that are largely consistent with economic theories of the labor market.

Our second result shows that the fraction of up-the-productivity-ladder transitions varies significantly across job flow types and across firm productivity levels. They are more likely and associated with larger productivity differentials for direct job-to-job transitions than for workers passing thorough non-employment spells. This is consistent with standard job-search theory, in the sense that movements resulting from on-the-job search should lead to better quality jobs more commonly available at higher productivity firms. They are also more likely to occur between firms at the high end of the productivity distribution, with up-the-ladder transitions originating from low productivity firms happening less frequently than implied by completely random transitions.

Our third result is that the contributions to overall reallocation-based productivity gains are very heterogeneous across different types of individuals. The job transitions of younger workers, workers with high skills, and female workers are associated with larger average productivity gains and explain the lion's share of productivity gains in the economy, significantly more than their share of transitions. The net contributions of other large groupings are modest or even negative. Workers with the highest turnover rates contribute proportionally little to aggregate productivity growth. Therefore, overall reallocation gains are largely explained by the movements of a relatively narrow set of workers.

Overall, our findings sound a note of caution about, or at least modesty in interpretation of, the connections between labor market fluidity and aggregate productivity growth. While fluidity enables reallocation of resources to more productive firms, many of the observed job transitions appear to happen for reasons that are orthogonal to industry or aggregate productivity growth. The flip side of this coin is that there may be a substantial amount of untapped potential for labor reallocations to enhance productivity growth.

These results also show very disparate labor market experiences for different types of workers. While for some workers job transitions are rare and tied to large movements up the productivity ladder, other workers change jobs frequently and these movements are seldom related to systematic reallocation gains. The heterogeneity appears related to the underlying distribution of skills and human capital as well as firms' technologies and productivity levels.

Our paper relates to several strands of literature. The first are studies documenting and analyzing the existence of persistent productivity differences across firms, and the potential efficiency gains of unrealized labor reallocation (Hsieh and Klenow, 2009; Restuccia and Rogerson, 2013; Dias et al., 2016). A second literature looks more directly at the role of actual employment reallocation across firms as a relevant driver of aggregate productivity growth (De Loecker and Konings, 2006; Foster et al., 2008; Syverson, 2011; Melitz and Polanec, 2015). These papers are closest to the spirit of our analysis, as they provide quantitative evidence of the importance of net reallocation on the aggregate. We contribute to their insights by directly quantifying flows along the productivity ladder at the worker level, including the contributions of different types of job flows and worker types to aggregate productivity gains. A third body of work studies the determinants and implications of individual job transitions (Topel and Ward, 1992; Fallick et al., 2011; 
Davis et al., 2012; Foster et al., 2016; Sorkin, 2018) and, more recently, links such transitions to movements along job ladders from the perspective of workers' career trajectories (Menzio et al., 2016; Lise and Robin, 2017; Moscarini and Postel-Vinay, 2018; Bagger and Lentz, 2019). Our results are generally consistent with their findings, but add to them by linking workers' job transitions to the productivity gaps between firms.

We describe our data and methodology in the next section, and provide a first glimpse at reallocation flows. Section 3 presents evidence of overall efficiency gains from job flows, differentiating by job transition type and by firm of origin productivity levels. Section 4 further studies the role of heterogeneity at the worker level, and provides a direct quantification of the relative contribution of different groups to aggregate productivity-gains. Section 5 concludes.

\section{Data and Methodology}

Our data comes from two main sources. First, the Chilean tax authority, SII, provides tax records for the universe of Chilean firms from 2005 through 2016. The annual tax statement (F22) provides information on each firm's balance sheet, including data on sales, expenditures in intermediate inputs, the wage bill, and proxy for capital stocks (immobile assets). Additionally, firms file a labor compensation report (DJ1887) that records the annual compensation paid to each employee and the specific months in which she was employed at the firm. We use this information to build a monthly matched employeremployee dataset in which we observe the employment status of an individual worker, earnings, and any job transitions. Because all formal firms must report to the SII, the data covers any worker with a formal wage contract. This represents roughly $60 \%$ of all employment in Chile. All data are anonymized to ensure confidentiality of firms' and workers' identities.

Second, we obtain workers' genders and dates of birth from the Chilean Civil Registry and Identification Service (Servicio de Registro Civil e Identificación) and match it to the SII data.

We apply a set of filters to obtain the final dataset in our empirical analysis. First, we drop all firms that have only one employee for an entire year, as it seems likely that they represent some form of self-employment rather than an actual firm with workers in the spirit of our exercise. We also drop all workers employed in those firms. This is about $1.7 \%$ of the initial set of 48 million monthly worker-job matches. Second, we want to avoid spurious job transitions in which workers move to a "new" firm with a different tax ID that is actually directly linked to the previous firm. This includes cases in which the firm tax ID changes, M\&As, or separations of a single firm into several business entities for tax reasons. We address this by excluding from the set of transitions all cases in which a significant share of a firm's workforce jointly reallocates to another firm, whether existing or new. This removes just under 5000 firms. ${ }^{1}$ Third, we must assign any workers

\footnotetext{
${ }^{1}$ We use a sliding scale to define en masse transitions likely to reflect spurious firm changes. Namely, we do not consider job transitions where the following fractions of workers in a firm of a given size category jointly move to the same firm: $100 \%$ of workers in firms with $4-5$ employees, $90 \%$ of workers in firms with 6-10 employees, $80 \%$ of workers in firms with 11-20 employees, $70 \%$ in firms with 21-50 employees,
} 
employed by more than one firm in a given month to a single job and employer. We classify the worker's main job as the one with the longest current tenure and, if there is a tie, the one with the highest average monthly earnings. About $8 \%$ of our worker-job observations are dropped as secondary jobs. Finally, as we want to focus on full-time jobs but have no information on hours, we drop all employment relations in which the worker earns an implied full-time wage that is less than the minimum wage for $80 \%$ of her tenure. These jobs, which account for $20 \%$ of the initial set of observations, are probably part-time.

In line with the literature on aggregate productivity growth and reallocation, our measure of productivity is defined at the firm level. We calculate average labor productivity as a measure of annual sales (from form F22) per annual-equivalent worker. Firms' annual-equivalent workers are simply the sum of workers in firms' monthly DJ1887 reports, divided by 12. For example, a firm with one worker who is employed the entire year and two employees who each work in six months of the year (whether overlapping months or not) has two annual-equivalent employees. ${ }^{2}$ This is our preferred productivity specification, as it relates more directly to previous literature and allows us to work with a wider set of firms. For robustness, we also calculate the marginal revenue product of labor constructed using the methodology in Ackerberg et al. (2015), although the fact that not all firms report capital implies that we have a smaller set of firms and transitions.

We define job transitions as changes in the firm identity tied to the worker's main job. If this occurs over two consecutive months, we consider it a job-to-job transition. If there is a gap of a month or more between jobs, we label it as a transition through a non-employment spell. This could reflect unemployment, exit from the labor force, or given the limits of our data, a spell of employment in the informal sector.

We do not have worker education data, so we use workers' earnings to classify them into skill groups. We follow the methodology proposed by Borovičková and Shimer (2017), who define a worker's skill type as the expected wage she should receive in an employment relationship, conditional on accepting the job. This provides a measure of the market's valuation of the worker's skills, reflecting human capital acquired through both education and experience. Results throughout the paper are robust to simpler methodologies, such as a worker's earnings quantile within gender-cohort groups.

To compute the Borovičková and Shimer (2017) skill group, we first obtain the residual from a regression of logged monthly real earnings of worker $i$ in firm $j$ and year $t, w_{i j t}$, on indicators for the year, $d_{t}$, as well as for the worker's age-by-gender group, $d_{a, g}$. The regression is shown in equation 1.

$$
w_{i j t}=\beta_{0}+\beta \sum_{t=2005}^{2016} d_{t}+\delta \sum_{a, g} d_{a, g}+\varepsilon_{i j t}
$$

$60 \%$ in firms with 51-100 employees, $50 \%$ in firms with 101-200 employees, or $20 \%$ in firms with over 200 employees. These thresholds are of course rather arbitrary, but results were not affected when choosing different reasonable thresholds.

${ }^{2}$ For consistency with the concept of labor productivity, we include all workers employed in the firm at any given month, regardless of whether they had multiple jobs. 
We average this residual through each worker's observed employment history to obtain an estimate of the worker's type. We then rank workers by type into quintiles, weighting by the worker's observed length of employment. Because the methodology removes the time component of wages, this worker ranking is time-invariant and comparable across the sample.

We also classify workers based on their job turnover propensity. Using observed job tenure histories, we run Cox survival regressions on the duration of employment spells, including those that remain open at the end of the sample. These hazard models control for gender and age. The residuals are ranked and workers sorted into separation hazard quintiles. These residuals reflect an estimate of an individual worker's idiosyncratic propensity toward high or low job turnover.

\subsection{A First Look at Reallocation Patterns}

Before we start our main exercises, we use our data to replicate the analysis in Haltiwanger et al. (2018), who look at job-to-job flows between low and high productivity firms (what they call "poaching flows") in the US across different worker categories. This exercise serves two purposes. First, it provides some insights from recent literature on firm-level reallocation that can motivate our subsequent worker-level analysis. Second, it allows a comparison of the reallocation patterns observed in the US with those in our Chilean data. As discussed below, the fact that these patterns look very similar for both countries suggest that our results might have more general implications beyond the Chilean economy.

Haltiwanger et al. (2018) place firms into productivity quintiles and focus on net jobto-job flows at the lowest and highest quintiles. ${ }^{3}$ Their results show that net job-to-job flows are consistent with productivity-enhancing reallocation. Net flows are negative for low-productivity firms and positive for high-productivity firms. However, net inflows into high-productivity firms are not homogeneous across types of individuals. Younger and more educated workers are over-represented.

We find very similar patterns in Chile. Net job-to-job flows are negative (positive) for low (high) productivity firms across all worker categories. Therefore, on the net, reallocation enhances productivity, as more workers move towards high-productivity firms. More interestingly, though, poaching is far from uniform across all workers. This can be seen in Table 1.

Panel A presents poaching patterns across four age groups: workers younger than 25 years old, 25-34 years old, 35-44 years old, and 45 and older. Column (1) presents the worker age groups' shares of all job-to-job transitions in the sample, while column (2) reports the groups' shares of job-to-job transitions out of firms in the lowest productivity quintile. As is clear in column (3), which reports the ratio of these two shares, workers poached from these low-productivity firms are considerably younger. Even though those under 35 account for only $44 \%$ of transitions, they are $73 \%$ of poached workers. Workers

\footnotetext{
${ }^{3} \mathrm{As}$ in our main specification, their productivity metric is the average product of labor.
} 
Table 1: Poaching Patterns by Worker Type

\begin{tabular}{|c|c|c|c|c|c|}
\hline & \multirow[b]{2}{*}{$\begin{array}{c}\text { Share in the } \\
\text { economy } \\
(1)\end{array}$} & \multicolumn{2}{|c|}{ Low Productivity } & \multicolumn{2}{|c|}{ High Productivity } \\
\hline & & $\begin{array}{c}\text { Net } \\
\text { Job-to-job } \\
(2)\end{array}$ & $\begin{array}{c}\text { Ratio } \\
(3)\end{array}$ & $\begin{array}{c}\text { Net } \\
\text { Job-to-job } \\
(4)\end{array}$ & $\begin{array}{c}\text { Ratio } \\
(5) \\
\end{array}$ \\
\hline \multicolumn{6}{|c|}{ Panel A: By age } \\
\hline Less than 25 & 13.0 & 26.7 & 2.05 & 14.2 & 1.09 \\
\hline Age $25-34$ & 31.1 & 46.6 & 1.50 & 48.1 & 1.55 \\
\hline Age $35-44$ & 26.5 & 19.4 & 0.73 & 24.3 & 0.92 \\
\hline Age 45 or older & 29.4 & 7.3 & 0.25 & 13.4 & 0.45 \\
\hline \multicolumn{6}{|c|}{ Panel B: By worker skill type } \\
\hline Low wage & 23.4 & 10.0 & 0.43 & 5.8 & 0.25 \\
\hline Q2 & 23.3 & 24.7 & 1.06 & 15.7 & 0.67 \\
\hline Q3 & 20.6 & 29.5 & 1.43 & 22.9 & 1.11 \\
\hline Q4 & 17.3 & 25.8 & 1.49 & 28.9 & 1.67 \\
\hline High wage & 15.4 & 10.0 & 0.65 & 26.7 & 1.74 \\
\hline
\end{tabular}

Note: This table summarizes net job-to-job transitions by age and worker skill categories. Following Haltiwanger et al. (2018), we define high- (low-)productivity firms as the top (bottom) quintile in the firm labor productivity distribution.

Source: Authors' calculations based on Chilean SII data. 
over 45 , while almost $30 \%$ of transitions, represent a scanty $7 \%$ of workers who leave lowproductivity firms. This is not completely a phenomenon of low-productivity firms. If we focus on poaching from firms in the highest productivity quintile, as shown in columns (4) and (5), the age pattern is not as strong yet still remains. More than $60 \%$ of workers poached from these firms are younger than 35, and those over 45 are underrepresented.

Panel B repeats the exercise for worker skill groups, where worker skills are proxied by the lifetime earnings quintiles defined in Section 2. Once again, poaching patterns are far from homogeneous. Here, the strongest patterns regard transitions away from the highest-productivity firms. These are disproportionately high-skill (high-wage) workers, with the highest skill quintile accounting for 1.7 times as many transitions from the most productive firms as their overall share of transitions. Poaching from the lowestproductivity firms is qualitatively similar but of smaller magnitude.

Overall, the results in Table 1 indicate that worker heterogeneity is tied to systematic differences in reallocation patterns, a result that we will exploit in more detail and in an aggregate context in Section 3. Additionally, the similarity between these results and those in Haltiwanger et al. (2018) also suggest that Chile's labor market is not exceptional and its behavior can have implications beyond the market context of this paper.

\section{Job Transitions and Productivity Sorting Patterns}

We begin our main analysis by relating individual worker transitions between firms to differences in those firms' labor productivity levels.

For each transition, we calculate the difference between the logged labor productivity levels of the destination and origin firms. This measures both the direction of any given transition - whether the worker went up or down the productivity job ladder - as well as the magnitude of the change. We present statistics of this distribution in Table 2.

Panel A presents the results across all 10 million transitions in our sample. Consistent with reallocation being an important factor behind productivity growth, the average labor productivity gap between the destination and origin firm in a worker transition is almost $9 \%$. However, this aggregate result averages over enormous heterogeneity. This is clear in the large dispersion of the productivity differentials. The 25th percentile of the distribution involves a worker moving to a firm with a labor productivity level about half the size $\left(e^{-0.635}=0.53\right)$ of the firm she left. The 75 th percentile transition is to a firm with a productivity level more than twice as high $\left(e^{0.790}=2.20\right)$. The rough symmetry of this dispersion is reflected in the fact that the share of job transitions that move up the productivity ladder is only a shade above half, with $47.6 \%$ of worker transitions being to firms less productive than the origin firm.

This is a striking result. While net reallocation flows are directed towards more productive firms, the process involves an enormous degree of churning in both directions. 
Table 2: Job Transitions and Productivity Gaps

\begin{tabular}{|c|c|c|c|c|c|c|}
\hline & $\begin{array}{c}\text { Average } \\
\text { Productivity } \\
\text { Gap } \\
\text { (1) }\end{array}$ & $\begin{array}{l}\mathrm{p} 25 \\
(2)\end{array}$ & $\begin{array}{l}\mathrm{p} 50 \\
(3)\end{array}$ & $\begin{array}{l}\text { p75 } \\
\text { (4) }\end{array}$ & $\begin{array}{c}\text { Share } \\
\text { Upward } \\
\text { Trans. } \\
(5)\end{array}$ & $\begin{array}{c}\text { Transi- } \\
\text { tions } \\
(6)\end{array}$ \\
\hline \multicolumn{7}{|c|}{ Panel A: Labor Productivity } \\
\hline All & 8.86 & -63.48 & 5.48 & 78.99 & 52.43 & $10,421,977$ \\
\hline Job-to-job & 18.48 & -51.38 & 9.69 & 83.30 & 54.69 & $4,106,039$ \\
\hline Job-N-job & 2.60 & -71.68 & 2.32 & 76.41 & 50.96 & $6,315,938$ \\
\hline \multicolumn{7}{|c|}{ Panel B: Adjusted Labor Productivity } \\
\hline All & 6.64 & -63.87 & 3.81 & 75.05 & 51.71 & $10,421,977$ \\
\hline Job-to-job & 16.83 & -51.51 & 9.22 & 80.69 & 54.41 & $4,106,039$ \\
\hline Job-N-job & 0.01 & -72.14 & -0.11 & 71.62 & 49.96 & $6,315,938$ \\
\hline
\end{tabular}

Note: Productivity measured as log average labor productivity. Productivity gaps are defined as the difference between the destination firm and origin firm for any given job transition. Values multiplied by 100 for readability. "Upward transitions" are defined as job transitions with a positive productivity gap. Source: Authors' calculations based on Chilean SII data.

Of course, even in a frictionless world without uncertainty in which all job transitions were efficient, not all transitions would be up the productivity ladder. As is standard in the reallocation literature, our measures of productivity gains at the firm level are not worker-specific. In reality, however, the marginal product of labor in a given firm might differ across workers. In that case, worker movements could be motivated by better firmworker specific matches, and our aggregate measure of firm productivity might not reflect the relevant marginal productivity of each individual worker in a given match. Workers can also move due from other non-pecuniary motives that might drive worker reallocation across different firms (Sorkin, 2018). Finally, even if the absence of worker-specific effects, productivity measures (and therefore productivity gaps) can be subject to mismeasurement.

Nonetheless, the fact that the frequency of upward flows is only marginally higher than that of a completely random reallocation benchmark, with a $50 \%$ unconditional change of moving up or down the firm-productivity ladder, is notable, and a result that sheds new light on the process underlying net reallocation. Further research might offer further understanding of the extent to which this is related to various search, spatial, and regulatory frictions in the labor market, given the underlying distributions of productivity and worker characteristics.

To our knowledge, there is little comparable evidence available in the prior literature. A notable exception is a result in Stoyanov and Zubanov (2012), who study labor flows and productivity in Denmark's manufacturing sector. Their research focus is different from ours, centering on the potential externalities created when workers from more to less productive firms, rather than a comprehensive characterization of reallocation and productivity on the aggregate. However, they do mention the share of upward transitions 
in their data is $55 \%$. This figure is slightly higher but still very close to our findings, suggesting once again that this result is not an artifact of this particular dataset.

The second and third rows of Panel A show the separate distributions for direct jobto-job transitions and those broken by a spell outside formal employment (job-N-job). Job-to-job transitions, which can be classified as poaching from the destination firm, are $39 \%$ of transitions in our sample. They are associated with larger average productivity gaps between destination and origin firms, and indeed the whole distribution of productivity differentials shifts to the right. Workers that change jobs directly are therefore more likely to climb productivity ladders and their movements correspond to larger productivity differentials. In fact, if we sum all productivity changes tied to every reallocated worker, job-to-job transitions account for more than $80 \%$ of this implied aggregate productivity gain.

This pattern is consistent with the presence of search frictions in the reallocation process. The idea of on-the-job search introduced by Burdett and Mortensen (1998) implies that direct job-to-job transitions are likely to represent voluntary movements to better matches. To the extent that match qualities correlate positively with measures of firmlevel productivity, there should be a link between direct job-to-job transitions and worker moving upwards through a productivity ladder. On the other hand, the productivityenhancing effects of indirect job transitions, where the worker goes through an intervening spell without formal employment, are plausibly weaker. For example, a worker who experienced an involuntary separation from her prior employer and had to find work might end up accepting a worse match, as long as it satisfies her reservation wage.

All this said, while the share of upward transitions is larger among job-to-job transitions, the fraction is still relatively close to $50 \%$. Even direct job-to-job transitions reflect a very noisy reallocation process.

Panel B addresses a potential concern regarding the exercise shown in Panel A. As discussed earlier, our data defines firm productivity by calendar years. Transitions that occur between calendar years compare productivity measures across different points in time. Secular aggregate productivity growth implies that the average true productivity gaps for across-year transitions would be overestimated. Additionally, the raw productivity gap does not account for systematic differences in average labor productivity across sectors, which are likely related to differences in capital intensity. We therefore adjust productivity across years by subtracting from the measured destination-origin productivity difference both the average annual productivity growth over the period as well as, for transitions across sectors, the difference in mean sector productivity levels.

After this adjustment, the average productivity gaps do become smaller, with the average differential for all transitions falling to about $6.6 \%$, and $51.7 \%$ of transitions being upwards. Most of the basic patterns in Panel A remain, however. The biggest difference is that the average and median productivity gaps of job-N-job transitions are negligible. For the rest of the paper, our attention will mainly focus on this measure of adjusted labor productivity differences across transitions, although all results are qualitatively robust to using the unadjusted gaps summarized in Panel A. 
We also show in Appendix A.1 that the gist of our results also hold if productivity differentials are calculated using the marginal revenue productivity of labor described in Ackerberg et al. (2015), either using the number of workers or the total wage bill (as a proxy for quality-adjusted labor). Appendix A.2 shows that the qualitative results are robust to focusing on job transitions within specific economic sectors, like manufacturing or services, while Appendix A.3 replicates the results using an alternative timing for productivity. Namely, productivity in the origin firm is calculated one year before separation and productivity in the destination firm one year after the new match.

To have a sense of the macroeconomic scale of the reallocation process described by the data, we sum sales per worker gaps across all job transitions that take place during a given year and then divide that sum by firms' total sales that year. This calculation assumes each transition leads to an output change equal to what would happen if the transitioning worker experienced a labor productivity change equal to that between of the two firms she transitions between. The sum of these output changes relative to total output provides a metric of output growth coming from productivity gains through labor reallocation. Over our sample period, the implied average annual sales growth from reallocation computed in this way is $1.58 \%$. For comparison, average annual total sales growth in our data is $6.1 \%$. This suggests that labor reallocation from lower to higher marginal product activities is quantitatively important as a potential source of growth.

\subsection{Job Transitions and the Distribution of Firm Productivities}

Figure 1 presents another way to summarize the connections between labor reallocation and productivity. It plots, for every percentile of the firm productivity distribution, the probability that a given worker transition from an origin firm at that percentile is to a destination firm with a higher productivity level. If worker reallocations were entirely unrelated to productivity differentials, the probability would be given by a negative 45-degree line. For example, a transitioning worker leaving an origin firm at the 25th percentile would have a 75 percent probability of moving to a higher-productivity firm. As the figure shows, actual reallocation patterns depart from the random benchmark, but modestly so, and the deviation from randomness varies systematically through the productivity distribution. Movements up the productivity ladder are disproportionately likely among workers employed by firms in the upper half of the productivity distribution. In contrast, workers leaving firms at the lower tail of the productivity distribution are more likely to move to an even lower-productivity firm than if they moved randomly. ${ }^{4}$

\footnotetext{
${ }^{4}$ Appendices A.1 to A.3 present the same exercise for transitions using the MPL as a measure of productivity, different economic sectors, and a different timing for productivity.
} 
Figure 1: Conditional probability of moving to a more productive firm

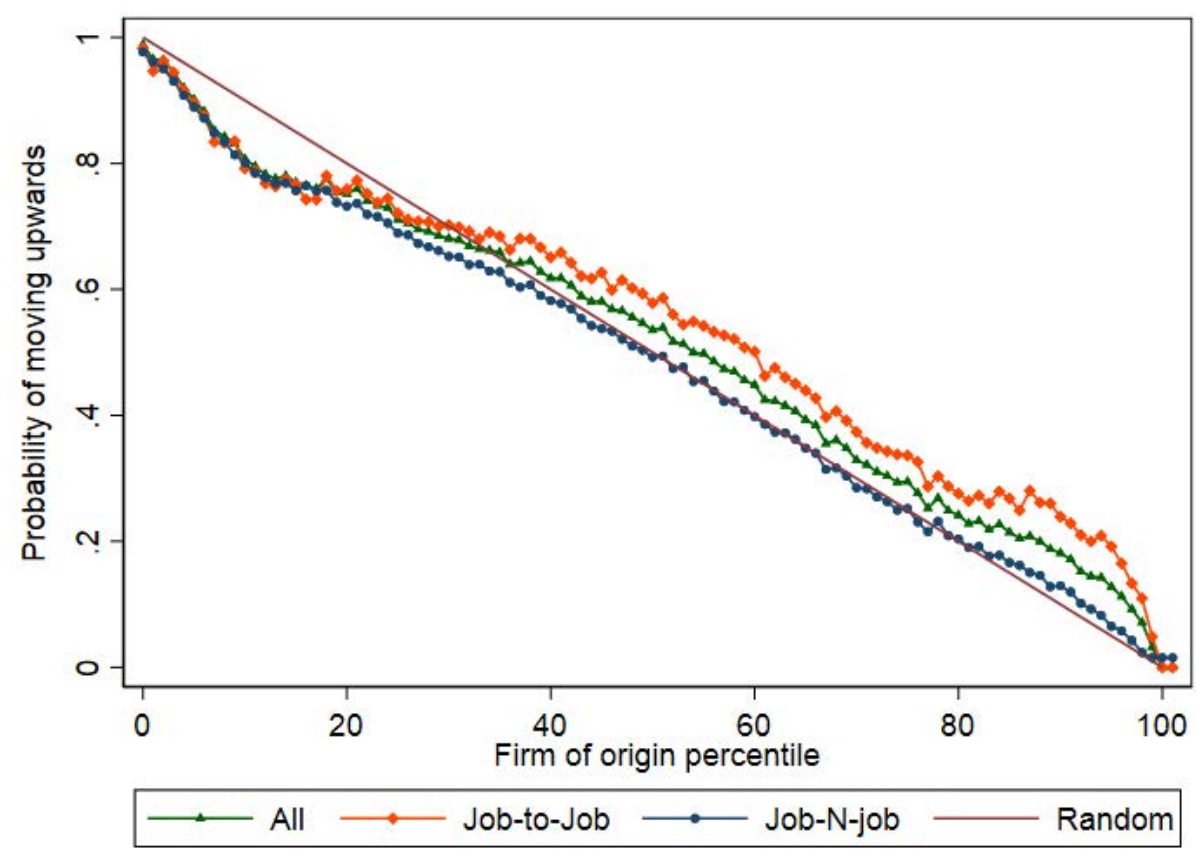

Note: Job transitions are sorted by adjusted labor productivity of the firm of origin. For each percentile of this distribution, the figure plots the share of transitions to a more productive firm.

Source: Authors' calculations based on Chilean SII data.

It is also interesting that at the bottom end of the productivity distribution, job-to-job and indirect transitions look virtually identical. For workers at low-productivity firms, there seems to be no systematic difference between changing jobs directly or indirectly in terms of the likelihood of moving up the productivity ladder. In contrast, the two types of transitions look very different at the upper end of the productivity distribution. Indirect transitions lie (almost) along the random reallocation benchmark, but job-to-job transitions are much more likely to lead to movements up the job ladder.

These results suggest that the labor market is segregated to some extent, with workers in low productivity firms moving mostly to similar or even less productive firms, while workers on the upper end of the distribution tend to move up the productivity ladder. To analyze this in further detail, we classify firms in productivity deciles, and calculate the transition matrix of all job movements across firms. Table 3 depicts the results. Each row represents the share of transitions originating in each given productivity decile that end up in each of the ten destination deciles. Under random reallocation all cells would equal 0.1. The colors in the heat map depict the intensity of the connection between deciles.

The heat map shows that job transitions occur across the whole productivity spectrum, with frequencies for all decile pairs being at least 0.07 . This is once again consistent with the idea that reallocation at the individual level is a noisy process. Despite this, it is clear that the transition matrix is inconsistent with randomness: transitions are much most frequent around the diagonal, so workers have a higher probability of moving within the same decile or to an adjacent one. In fact, in all cases transitions to firms within the same decile are the most likely, a result that is especially strong for transitions originating 
at either end of the productivity distribution. For transitions originated in the lowest productivity decile, $21 \%$ go to firms within the same decile. The comparable figure of the tenth decile is $24 \%$. Consistent with the insights in Figure 1, movements to the downward adjacent decile are marginally more likely than movements upwards for transitions originating in deciles in the lower end of the productivity distributions (2 to 4 ). This flips for deciles in the upper end.

Table 4 repeats the exercise, but only for direct job-to-job transitions. As before, most transitions fall around the diagonal. However, transitions to more productive deciles are more common in the upper half of the productivity distribution. For example, while $30 \%$ of overall transitions originating in decile 7 are to firms in the top 3 deciles, in the case of job-to-job transitions the figure grows to $35 \%$. It is also interesting to notice that while almost a quarter of job-to-job transitions starting from the lowest decile are to firms within the same decile, a similar number goes to firms in the highest two deciles. That is, transitions that climb the entire productivity ladder in one swoop, which are associated with very large productivity gains, are not that infrequent. In fact, among all deciles, only job-to-job transitions originating from the ninth decile have a higher probability of ending up in the tenth than those starting from the bottom decile.

This look at individuals' transitions across the distribution of productivities complements our earlier results in several dimensions. First, it shows that the process of reallocation is not homogeneous, and varies significantly across the productivity distribution, with productivity-enhancing reallocation being much more likely in the upper end of the distribution, especially so for direct transitions. Second, transitions to firms with similar productivity are most likely, reinforcing the idea that overall reallocation up the productivity distribution is modest. Despite this, movements that span the distribution from the lowest to the highest rung are non-negligible.

Table 3: Share of Total Transitions Originated in Each Productivity Decile, by Productivity Decile of the Destination Firm

\begin{tabular}{|c|c|c|c|c|c|c|c|c|c|c|}
\hline & \multicolumn{10}{|c|}{ Destination } \\
\hline & d1 & d2 & d3 & d4 & d5 & d6 & d7 & d8 & d9 & d10 \\
\hline d1 & 0.21 & 0.14 & 0.10 & 0.08 & 0.07 & 0.07 & 0.07 & 0.07 & 0.09 & 0.09 \\
\hline d2 & 0.16 & 0.17 & 0.12 & 0.09 & 0.08 & 0.07 & 0.07 & 0.07 & 0.08 & 0.09 \\
\hline d3 & 0.10 & 0.13 & 0.15 & 0.12 & 0.10 & 0.09 & 0.08 & 0.08 & 0.08 & 0.08 \\
\hline d4 & 0.08 & 0.10 & 0.13 & 0.13 & 0.12 & 0.10 & 0.09 & 0.09 & 0.08 & 0.07 \\
\hline d5 & 0.07 & 0.08 & 0.11 & 0.12 & 0.13 & 0.12 & 0.11 & 0.10 & 0.09 & 0.07 \\
\hline d6 & 0.07 & 0.08 & 0.09 & 0.11 & 0.12 & 0.13 & 0.13 & 0.11 & 0.09 & 0.07 \\
\hline d7 & 0.07 & 0.07 & 0.08 & 0.10 & 0.11 & 0.13 & 0.13 & 0.12 & 0.10 & 0.08 \\
\hline d8 & 0.07 & 0.07 & 0.08 & 0.09 & 0.11 & 0.12 & 0.13 & 0.13 & 0.11 & 0.09 \\
\hline d9 & 0.08 & 0.08 & 0.08 & 0.08 & 0.09 & 0.10 & 0.11 & 0.12 & 0.14 & 0.13 \\
\hline d10 & 0.09 & 0.08 & 0.07 & 0.07 & 0.08 & 0.07 & 0.08 & 0.10 & 0.14 & 0.23 \\
\hline
\end{tabular}

Note: Firms associated to job transitions are sorted by adjusted labor productivity and divided by deciles. For each origin decile, the table presents the share of transitions going to each destination decile. Source: Authors' calculations based on Chilean SII data. 
Table 4: Share of Job-to-Job transitions Originated in Each Productivity Decile, by Productivity Decile of the Destination Firm

\begin{tabular}{|c|c|c|c|c|c|c|c|c|c|c|}
\hline & \multicolumn{10}{|c|}{ Destination } \\
\hline & d1 & d2 & d3 & d4 & d5 & d6 & d7 & d8 & d9 & d10 \\
\hline d1 & 0.23 & 0.14 & 0.09 & 0.07 & 0.06 & 0.06 & 0.06 & 0.07 & 0.10 & 0.13 \\
\hline d2 & 0.16 & 0.18 & 0.11 & 0.08 & 0.07 & 0.07 & 0.06 & 0.07 & 0.08 & 0.12 \\
\hline \multirow{5}{*}{ 总 } & 0.09 & 0.13 & 0.15 & 0.11 & 0.10 & 0.09 & 0.08 & 0.08 & 0.08 & 0.10 \\
\hline & 0.07 & 0.09 & 0.13 & 0.13 & 0.12 & 0.11 & 0.09 & 0.09 & 0.08 & 0.09 \\
\hline & 0.05 & 0.07 & 0.10 & 0.12 & 0.13 & 0.12 & 0.12 & 0.10 & 0.09 & 0.09 \\
\hline & 0.05 & 0.06 & 0.08 & 0.11 & 0.12 & 0.14 & 0.14 & 0.12 & 0.09 & 0.09 \\
\hline & 0.05 & 0.05 & 0.07 & 0.09 & 0.11 & 0.14 & 0.14 & 0.14 & 0.11 & 0.09 \\
\hline d8 & 0.05 & 0.05 & 0.07 & 0.08 & 0.10 & 0.13 & 0.14 & 0.14 & 0.12 & 0.11 \\
\hline d9 & 0.06 & 0.06 & 0.06 & 0.07 & 0.08 & 0.09 & 0.12 & 0.13 & 0.16 & 0.17 \\
\hline d10 & 0.07 & 0.06 & 0.06 & 0.06 & 0.06 & 0.06 & 0.08 & 0.10 & 0.15 & 0.31 \\
\hline
\end{tabular}

Note: Firms associated to transitions are sorted by adjusted labor productivity and divided by deciles. For each origin decile, the table presents the share of job-to-job transitions going to each destination decile.

Source: Authors' calculations based on Chilean SII data.

\section{Job Transitions and Worker Heterogeneity}

In this section, we explore systematic differences in the labor reallocation-productivity relationship across observable worker types.

\subsection{Reallocation Patterns by Worker Groups: Worker-Level Ev- idence}

An enormous literature (Topel and Ward, 1992; Menzio et al., 2016; Lagakos et al., 2018) has documented the importance of worker life-cycles in shaping employment dynamics and the evolution of earnings. Job mobility is larger early in the employment life-cycle, consistent with both young workers starting to build their job ladders and having lower transition costs due to having built less sector- or firm-specific human capital. Earnings growth is also especially strong in the first decade of labor market participation, pointing to fast accumulation of skills and rapid movement to better job matches. Workers in the later portions of their work lives, on the other hand, move significantly less, have flatter earnings profiles, and suffer significantly more from job displacements. It is not surprising that younger workers would play a leading role in employment reallocation towards more productive firms.

Separately, there are reasons why movements up the productivity ladder might be more likely for workers in the upper end of the ability distribution. Complementarities between high-productivity firms and high-skilled workers would naturally lead to sorting as an equilibrium outcome. It also seems likely that high-skilled workers have more mobility, all else equal, and can more easily adapt to a wider set of tasks and technologies across sectors.

To explore these elements further and complement our firm-heterogeneity results in 
the previous section with worker-heterogeneity results, we place every worker into one of 25 age-by-skill worker groups. These use the five skills quintiles described in Section 2, as well as five age groups (less than 25, 25-34, 35-44, 45-54, 55+). We compute the average productivity gap associated with worker transitions within each group. We take further advantage of our data to introduce one additional dimension by dividing the sample into men and women. This is a particularly interesting dimension for an economy like Chile, in which the gender wage gap is large and female labor participation, while growing, is still low.

Figure 2 graphs the results. The differences across groups reflect some remarkable patterns. ${ }^{5}$ Consistent with the discussion above, productivity differentials are significantly larger for young, skilled workers. They are the largest for workers younger than 25 and in the top skill quintile. Productivity gaps decline monotonically with age, even conditioning on skill, becoming almost negligible for workers over 45. They also tend to increase with worker skill, conditioning on age. The one group where the average productivity difference between the destination and origin firm is clearly negative is for high-skilled workers over 55. This may reflect that a large share of those transitions are non-voluntary and associated with the destruction of such workers' valuable job ladders. Comparing across genders, productivity gaps for a given age-skill group are consistently larger for female workers. The sole exception is the youngest, least-skilled group, where long time gaps between jobs are frequent. This indicates systematic gender-related difference in the process of labor reallocation.

Figure 2: Productivity gaps by worker characteristics

(a) Males

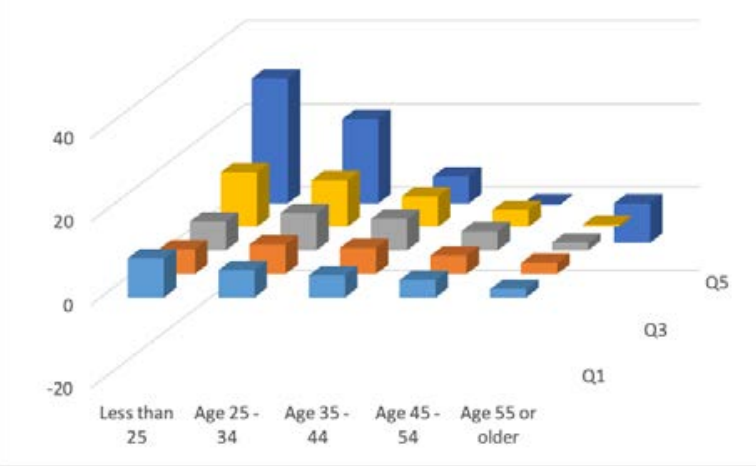

(b) Females

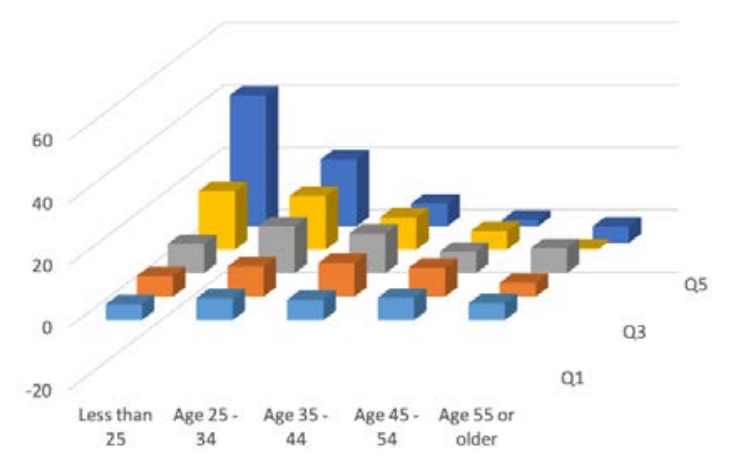

Note: The figure plots adjusted average productivity gaps resulting from job transitions, averaged by worker type group.

Source: Authors' calculations based on Chilean SII data.

Overall, these results are further evidence of the heterogeneity in the interaction between job transitions and productivity. Productivity-enhancing reallocation is significantly stronger among young, high-skilled, and female workers. We now use these results to decompose productivity gains from reallocation into group-level contributions, and provide a precise quantitative characterization of the relationship between individual

\footnotetext{
${ }^{5}$ Appendix A.1 shows the results using the marginal product of labor.
} 
transitions and aggregate gains.

\subsection{Taking Stock: Decomposing Aggregate Gains from Job Re- allocation across Different Groups}

We explore the aggregate implications of the heterogeneity documented above by decomposing the total implied productivity change from worker transitions into the portions accounts for by various worker subgroups. For each worker category, we calculate the contribution as the average productivity differential from job transitions within the group, weighted by the group's share of total transitions. As with the analogous exercise we did above for the aggregate, this assumes that each transitioning worker experiences a labor productivity change equal to the productivity gap (positive or negative) between her destination and origin firm. To the best of our knowledge, this decomposition of aggregate reallocation across worker characteristics is novel to the literature, and provides a quantitative assessment of the microeconomic structure that underlies macroeconomic reallocation. ${ }^{6}$

Table 5 presents the results. Column (1) decomposes the economy's average productivity gain from job transitions $(4.69 \%)$ into the absolute contributions by age group (Panel A), worker skill quintile (Panel B), gender (Panel C), and job tenure (turnover propensity) quintiles (Panel D). Column (2) reports the share of total reallocation accounted for by each group, while Column (3) reports the share of job transitions. Column (4) is the ratio of (2) to (3).

As suggested by the analysis in Figure 2, there is a lot of heterogeneity in implied productivity effects across different types of workers. Almost half of the economy's worker-reallocation-based productivity gains are associated with the job transitions of workers between 25 and 34 years old, and this rises to $76 \%$ if those under 25 are included. Productivity-enhancing labor reallocation is a young worker's game. Job transitions of workers between 45 and 54 contribute a meager $6 \%$, and those over 55 years old make a negative contribution. This once again reflects the strong life-cycle effect in reallocation patterns.

Column (4) highlights that these results reflect more than the fact that workers under 35 are more mobile. Their share of the implied productivity gain considerably exceeds their share of transitions. Younger workers not only transition more, they experience a larger productivity gap when they do move. ${ }^{7}$ As discussed above, these age-specific reallocation patterns closely relate to the literature on life-cycle income profiles (Lagakos et al., 2018; Menzio et al., 2016), which highlights that wage gains-likely associated with successful job transitions towards better matches - are especially relevant during the first decade of work experience.

The worker skill decomposition in Panel B shows that average productivity differentials are non-negative for all quintiles, but the relative contribution toward aggregate productivity growth rises monotonically with our skills measure. Transitions from workers in

\footnotetext{
${ }^{6}$ Appendix A.1 shows the results using the marginal product of labor.

${ }^{7}$ As mentioned earlier, they are also more likely to move directly through job-to-job transitions.
} 
the first quintile make no contribution to productivity growth through reallocation. Conversely, almost $60 \%$ of all reallocation gains come from the top two skill quintiles despite representing only $37 \%$ of transitions. In fact, while workers in the highest quintile move relatively infrequently (accounting only for $16 \%$ of all transitions), they explain more than a third of aggregate reallocation-based labor productivity gains. These results highlight that, conditional on switching jobs, more skilled individuals are more likely to move to a firm with larger labor productivity. Productivity job ladders among more skilled individuals are a relevant driver of reallocation-based productivity gains in the economy.

The third panel replicates the exercise for male and female workers. Female workers punch above their weight in terms of productivity gains through labor reallocation. While they account for only $20 \%$ of job transitions in the economy, they comprise $26 \%$ of reallocation-based aggregate productivity gains.

Table 5: Decomposition of Average Productivity Gains from Reallocation

\begin{tabular}{|c|c|c|c|c|}
\hline & Weighted gains & Share of total gains & Share of transitions & Gains-to-transitions ratio \\
\hline \multicolumn{5}{|c|}{ Panel A: By age } \\
\hline Less than 25 & 1.71 & $25.7 \%$ & $18.3 \%$ & 1.40 \\
\hline Age $25-34$ & 3.29 & $49.6 \%$ & $35.3 \%$ & 1.40 \\
\hline Age $35-44$ & 1.28 & $19.3 \%$ & $24.8 \%$ & 0.78 \\
\hline Age $45-54$ & 0.39 & $5.9 \%$ & $15.4 \%$ & 0.38 \\
\hline Age 55 or older & -0.03 & $-0.5 \%$ & $6.2 \%$ & -0.08 \\
\hline Total & 6.64 & & & \\
\hline \multicolumn{5}{|c|}{ Panel B: By worker skill quintile } \\
\hline Low Skill & 0.34 & $5.1 \%$ & $15.2 \%$ & 0.34 \\
\hline Q2 & 1.04 & $15.7 \%$ & $24.6 \%$ & 0.64 \\
\hline Q3 & 1.41 & $21.2 \%$ & $22.9 \%$ & 0.93 \\
\hline Q4 & 1.94 & $29.2 \%$ & $21.5 \%$ & 1.36 \\
\hline High Skill & 1.91 & $28.8 \%$ & $15.8 \%$ & 1.83 \\
\hline Total & 6.64 & & & \\
\hline \multicolumn{5}{|c|}{ Panel $C:$ By gender } \\
\hline Male & 4.90 & $73.8 \%$ & $79.9 \%$ & 0.92 \\
\hline Female & 1.74 & $26.2 \%$ & $20.1 \%$ & 1.31 \\
\hline Total & 6.64 & & & \\
\hline \multicolumn{5}{|c|}{ Panel D: By turnover propensity } \\
\hline Short job tenure & 0.53 & $7.9 \%$ & $29.3 \%$ & 0.27 \\
\hline Q2 & 1.19 & $17.9 \%$ & $32.4 \%$ & 0.55 \\
\hline Q3 & 1.92 & $28.9 \%$ & $23.6 \%$ & 1.22 \\
\hline Q4 & 2.31 & $34.8 \%$ & $12.9 \%$ & 2.70 \\
\hline Long job tenure & 0.70 & $10.5 \%$ & $1.9 \%$ & 5.61 \\
\hline Total & 6.64 & & & \\
\hline
\end{tabular}

Note: Weighted average productivity gains are the average productivity gap in a group's worker transitions weighted by that group's share of total transitions. Source: Authors' calculations based on Chilean SII data.

Panel D looks at the contribution of workers with different job tenures, based on the job turnover propensity regressions described in Section 2. Workers in the two quintiles with the shortest employment spells have a high turnover rate, and account for $61 \%$ of all transitions. However, they represent only $26 \%$ of total reallocation gains. The bulk of reallocation-based productivity gains come from quintiles 3 and 4 , which contribute 
$47 \%$ of all gains despite being only $29 \%$ of job transitions. Workers on the fifth quintile by definition seldom change jobs, and therefore represent a meager $1.9 \%$ of job transitions in the economy. Despite this, when they do move, they experience very large productivity gains, providing $11 \%$ of the overall productivity growth through worker reallocation. This general pattern is seen in the gains-to-transitions ratio in column (4), which increases strongly along the tenure groups and even more so than across skill levels.

Overall, these results reveal productivity ladders that are sharply distinct for different types of workers. Some workers only seldom change jobs, and when then do so they experience large average productivity gains. This is very different from the experience of workers that change jobs frequently, and whose movements show little correlation with systematic reallocation gains. These results seem similar in spirit to those discussed in the context of job transitions in the US, as seen recently in Gregory et al. (2021)

\section{Conclusions}

This paper provides a novel and more complete characterization of the relationship between individual job transitions and the aggregate process of employment reallocation that increases productivity by moving workers towards more productive firms.

Our results suggest that this process has a complex structure. The labor market's ability to reallocate workers away from less productive and into more productive firms involves an enormous amount of labor turnover, with a very large share of job transitions not leading to net productivity gains. Productivity-enhancing job transitions are not uniformly distributed, but instead exhibit significant and systematic differences across the distribution of firms and workers. Such transitions draw especially heavily from young, high-skill workers. Workers who change jobs the most frequently contribute proportionally the least to reallocation-based productivity growth. These patterns of heterogeneity, besides being informative about some theories of the labor market and serving as useful quantitative benchmarks, also demonstrate that a highly fluid labor market need not be an unequivocal sign of economy-wide productivity gains. 


\section{References}

Ackerberg, Daniel A, Kevin Caves, and Garth Frazer, "Identification properties of recent production function estimators," Econometrica, 2015, 83 (6), 2411-2451.

Albagli, Elías, Alejandra Chovar, Emiliano Luttini, Carlos Madeira, Alberto Naudon, and Matias Tapia, "Labor Market Flows: Evidence from Chile Using Micro Data from Administrative Tax Records," Working Papers Central Bank of Chile, 2017, 812.

Bagger, Jesper and Rasmus Lentz, "An empirical model of wage dispersion with sorting," The Review of Economic Studies, 2019, 86 (1), 153-190.

Bergoeing, Raphael, Facundo Piguillem, and Norman V Loayza, Why are developing countries so slow in adopting new technologies? The aggregate and complementary impact of micro distortions, The World Bank, 2010.

Borovičková, Katarína and Robert Shimer, "High wage workers work for high wage firms," Technical Report, National Bureau of Economic Research 2017.

Burdett, Kenneth and Dale T Mortensen, "Wage differentials, employer size, and unemployment," International Economic Review, 1998, pp. 257-273.

Busso, Matías, Lucia Madrigal, and Carmen Pagés, "Productivity and resource misallocation in Latin America," The BE Journal of Macroeconomics, 2013, 13 (1), 903-932.

Davis, Steven J, R Jason Faberman, and John Haltiwanger, "Labor market flows in the cross section and over time," Journal of Monetary Economics, 2012, 59 (1), 1-18.

Dias, Daniel A, Carlos Robalo Marques, and Christine Richmond, "Misallocation and productivity in the lead up to the Eurozone crisis," Journal of Macroeconomics, 2016, 49, 46-70.

Fallick, Bruce, John Haltiwanger, and Erika McEntarfer, "Nonemployment Duration and the Consequences of Job Separations," Unpublished. Accessed November, 2011, 15, 2011.

Foster, Lucia, Cheryl Grim, and John Haltiwanger, "Reallocation in the great recession: cleansing or not?," Journal of Labor Economics, 2016, 34 (S1), S293-S331.

_ , John Haltiwanger, and Chad Syverson, "Reallocation, firm turnover, and efficiency: Selection on productivity or profitability?," American Economic Review, 2008, 98 (1), 394-425.

Gregory, Victoria, Guido Menzio, and David G Wiczer, "The Alpha Beta Gamma of the Labor Market," Working Paper 28663, National Bureau of Economic Research April 2021.

Haltiwanger, John, Henry Hyatt, and Erika McEntarfer, "Who moves up the job ladder?," Journal of Labor Economics, 2018, 36 (S1), S301-S336. 
Hsieh, Chang-Tai and Peter J Klenow, "Misallocation and manufacturing TFP in China and India," The Quarterly Journal of Economics, 2009, 124 (4), 1403-1448.

Lagakos, David, Benjamin Moll, Tommaso Porzio, Nancy Qian, and Todd Schoellman, "Life cycle wage growth across countries," Journal of Political Economy, 2018, 126 (2), 797-849.

Lise, Jeremy and Jean-Marc Robin, "The macrodynamics of sorting between workers

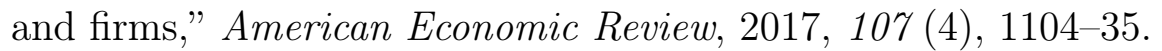

Loecker, Jan De and Jozef Konings, "Job reallocation and productivity growth in a post-socialist economy: Evidence from Slovenian manufacturing," European Journal of Political Economy, 2006, 22 (2), 388-408.

Melitz, Marc J and Sašo Polanec, "Dynamic Olley-Pakes productivity decomposition with entry and exit," The Rand Journal of Economics, 2015, 46 (2), 362-375.

Menzio, Guido, Irina A Telyukova, and Ludo Visschers, "Directed search over the life cycle," Review of Economic Dynamics, 2016, 19, 38-62.

Moscarini, Giuseppe and Fabien Postel-Vinay, "The cyclical job ladder," Annual Review of Economics, 2018, 10, 165-188.

Restuccia, Diego and Richard Rogerson, "Misallocation and productivity," Review of Economic Dynamics, 2013, 16 (1), 1-10.

Sorkin, Isaac, "Ranking Firms Using Revealed Preference," Quarterly Journal of Economics, 2018, 133 (3), 1331-1393.

Stoyanov, Andrey and Nikolay Zubanov, "Productivity spillovers across firms through worker mobility," American Economic Journal: Applied Economics, 2012, 4 (2), 168-98.

Syverson, Chad, "What determines productivity?," Journal of Economic literature, 2011, 49 (2), 326-65.

Topel, Robert H and Michael P Ward, "Job mobility and the careers of young men," The Quarterly Journal of Economics, 1992, 107 (2), 439-479. 


\section{Appendix A.1}

\section{Exercises using the Marginal Product of Labor}

Table 6: Job Transitions and Productivity Gaps

\begin{tabular}{|c|c|c|c|c|c|c|}
\hline & $\begin{array}{c}\text { Average } \\
\text { Productivity } \\
\text { Gap } \\
(1)\end{array}$ & $\begin{array}{l}\mathrm{p} 25 \\
(2) \\
\end{array}$ & $\begin{array}{l}\mathrm{p} 50 \\
(3)\end{array}$ & $\begin{array}{l}\text { p75 } \\
(4)\end{array}$ & $\begin{array}{c}\text { Share } \\
\text { Upward } \\
\text { Trans. } \\
(5)\end{array}$ & $\begin{array}{c}\text { Transi- } \\
\text { tions } \\
(6)\end{array}$ \\
\hline \multicolumn{7}{|c|}{ Panel A: Marginal Product of Labor (number of workers) } \\
\hline All & 7.7 & -59.4 & 5.1 & 72.9 & 52.4 & $6,764,893$ \\
\hline Job-to-job & 15.3 & -49.5 & 8.8 & 75.3 & 54.4 & $2,671,824$ \\
\hline Job-N-job & 2.7 & -66.1 & 2.5 & 71.3 & 51.1 & $4,093,069$ \\
\hline \multicolumn{7}{|c|}{ Panel B: Marginal Product of Labor (wage bill) } \\
\hline All & 2.2 & -51.5 & 1.1 & 54.9 & 50.6 & $6,764,888$ \\
\hline Job-to-job & 5.9 & -45.2 & 3.2 & 55.2 & 51.9 & $2,671,824$ \\
\hline Job-N-job & -0.3 & -55.7 & -0.4 & 54.7 & 49.8 & $4,093,064$ \\
\hline
\end{tabular}

Note: Firm productivity is defined as the marginal product of labor using the production function estimates obtained following the methodology in Ackerberg et al. (2015). Panel A uses the number of workers as the measure of labor while Panel B uses the wage bill. Productivity gaps are defined as the difference between the firm of destination and the firm of origin for any given job transition. Values multiplied by 100 for readability. "Upward transitions" are defined as job transitions with a positive productivity gap.

Source: Authors' calculations based on Chilean SII data. 
Figure 3: Conditional probability of moving to a more productive firm

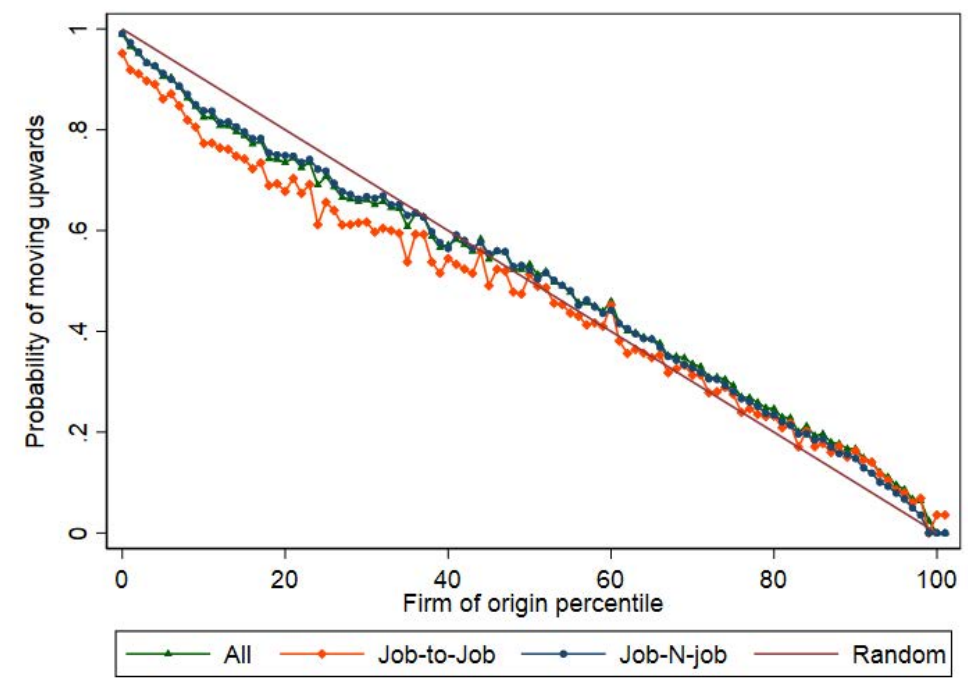

Note: Job transitions are sorted by the marginal product of labor of the firm of origin. The marginal product of labor is calculated using the production function estimates obtained following the methodology in Ackerberg et al. (2015), with labor defined as the firm's wage bill. For each percentile of this distribution, the figure plots the share of transitions to a more productive firm.

Source: Authors' calculations based on Chilean SII data.

Figure 4: Conditional probability of moving to a more productive firm

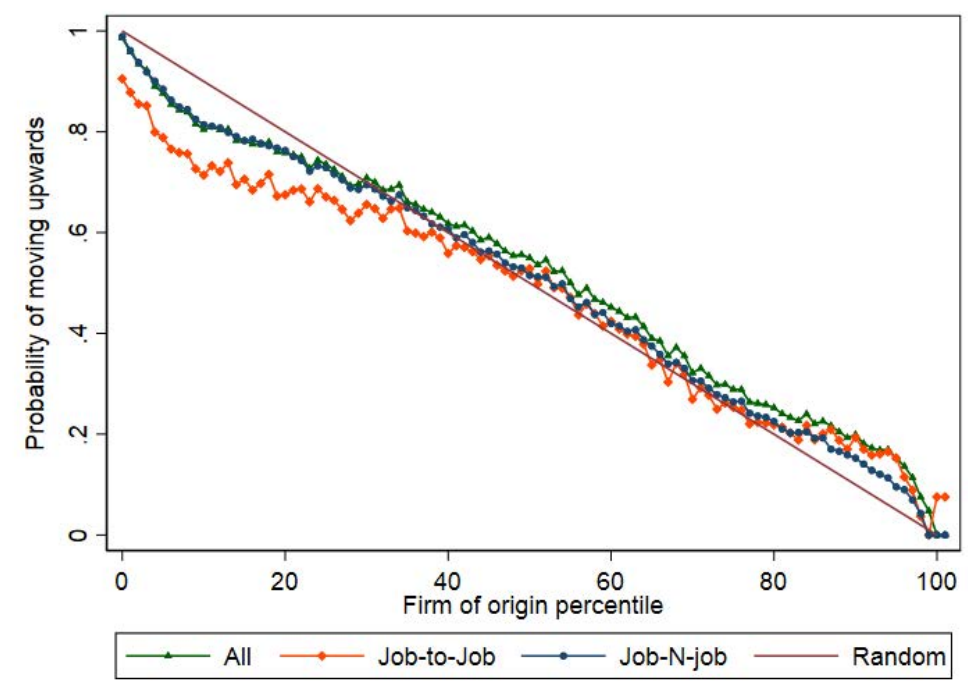

Note: Job transitions are sorted by the marginal product of labor of the firm of origin. The marginal product of labor is calculated using the production function estimates obtained following the methodology in Ackerberg et al. (2015), with labor defined as the firm's number of employees. For each percentile of this distribution, the figure plots the share of transitions to a more productive firm. Source: Authors' calculations based on Chilean SII data. 
Figure 5: Productivity gaps by worker characteristics

\section{(a) Males}

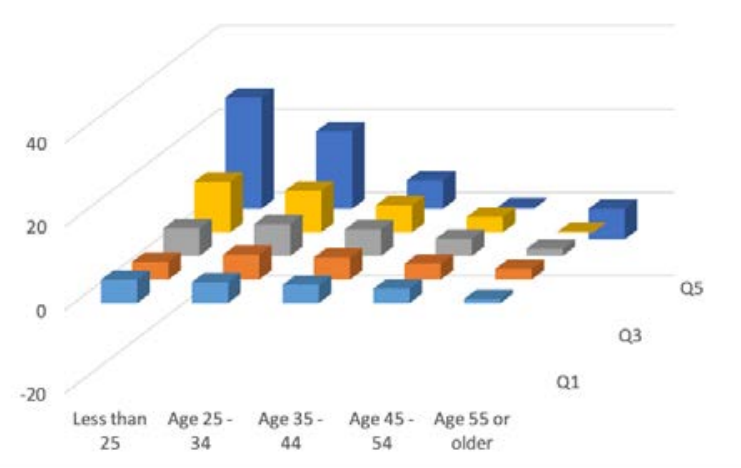

(b) Females

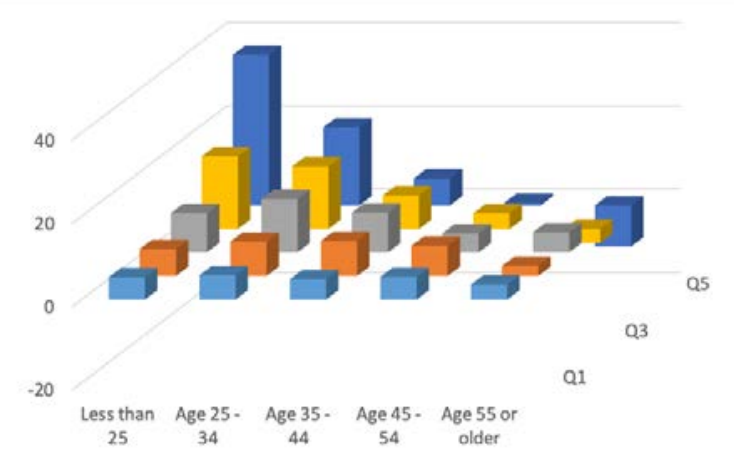

Note: The figure plots adjusted average productivity gaps resulting from job transitions, averaged by worker type group. Firm productivity is defined as the marginal product of labor using the production function estimates obtained following the methodology in Ackerberg et al. (2015) and using the number of workers as the measure of labor.

Source: Authors' calculations based on Chilean SII data.

Figure 6: Productivity gaps by worker characteristics

(a) Males

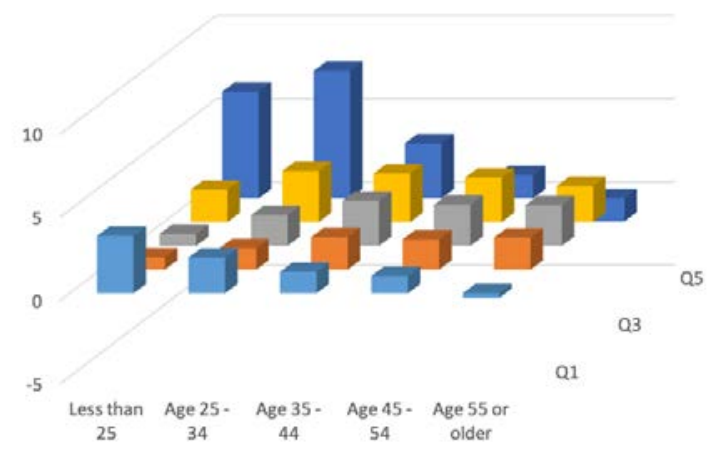

(b) Females

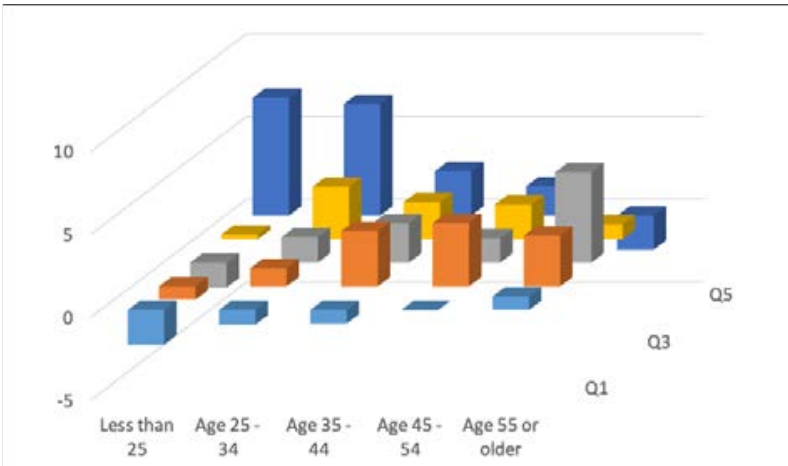

Note: The figure plots adjusted average productivity gaps resulting from job transitions, averaged by worker type group. Firm productivity is defined as the marginal product of labor using the production function estimates obtained following the methodology in Ackerberg et al. (2015) and using the wage bill as the measure of labor.

Source: Authors' calculations based on Chilean SII data. 
Table 7: Decomposition of Average Productivity Gains from Reallocation

\begin{tabular}{|c|c|c|c|c|}
\hline & $\begin{array}{l}\text { Weighted average } \\
\text { productivity gains } \\
(1)\end{array}$ & $\begin{array}{c}\text { Share of } \\
\text { productivity gains } \\
(2)\end{array}$ & $\begin{array}{c}\text { Share of job } \\
\text { transitions } \\
(3)\end{array}$ & $\begin{array}{l}\text { Gains-to- } \\
\text { transitions } \\
\text { ratio } \\
(4)\end{array}$ \\
\hline \multicolumn{5}{|c|}{ Panel A: By age } \\
\hline Less than 25 & 2.07 & $26.9 \%$ & $17.9 \%$ & 1.51 \\
\hline Age $25-34$ & 3.53 & $45.8 \%$ & $34.8 \%$ & 1.32 \\
\hline Age $35-44$ & 1.51 & $19.6 \%$ & $25.2 \%$ & 0.78 \\
\hline Age $45-54$ & 0.55 & $7.2 \%$ & $15.8 \%$ & 0.46 \\
\hline Age 55 or older & 0.03 & $0.4 \%$ & $6.3 \%$ & 0.06 \\
\hline Total & 7.70 & & & \\
\hline \multicolumn{5}{|c|}{ Panel B: By worker skill quintile } \\
\hline Low Skill & 0.61 & $7.9 \%$ & $14.9 \%$ & 0.53 \\
\hline Q2 & 1.30 & $16.9 \%$ & $24.4 \%$ & 0.70 \\
\hline Q3 & 1.58 & $20.5 \%$ & $22.6 \%$ & 0.90 \\
\hline Q4 & 2.07 & $26.9 \%$ & $21.8 \%$ & 1.23 \\
\hline High Skill & 2.14 & $27.8 \%$ & $16.3 \%$ & 1.70 \\
\hline Total & 7.70 & & & \\
\hline \multicolumn{5}{|c|}{ Panel C: By gender } \\
\hline Male & 5.91 & $76.7 \%$ & $82.6 \%$ & 0.93 \\
\hline Female & 1.79 & $23.3 \%$ & $17.4 \%$ & 1.34 \\
\hline Total & 7.70 & & & \\
\hline \multicolumn{5}{|c|}{ Panel D: By job tenures (turnover propensity) } \\
\hline Short job tenure & 1.08 & $14.1 \%$ & $30.3 \%$ & 0.47 \\
\hline Q2 & 1.66 & $21.5 \%$ & $32.3 \%$ & 0.67 \\
\hline Q3 & 2.01 & $26.1 \%$ & $22.9 \%$ & 1.14 \\
\hline Q4 & 2.25 & $29.2 \%$ & $12.7 \%$ & 2.31 \\
\hline Long job tenure & 0.70 & $9.0 \%$ & $1.9 \%$ & 4.71 \\
\hline Total & 7.70 & & & \\
\hline
\end{tabular}

Note:Firm productivity is defined as the marginal product of labor using the production function estimates obtained following the methodology in Ackerberg et al. (2015) and using the number of workers as the measure of labor. Weighted average productivity gains are the adjusted average productivity gap in a group's worker transitions weighted by that group's share of total transitions. Source: Authors' calculations based on Chilean SII data. 
Table 8: Decomposition of Average Productivity Gains from Reallocation

\begin{tabular}{|c|c|c|c|c|}
\hline & $\begin{array}{l}\text { Weighted average } \\
\text { productivity gains } \\
(1)\end{array}$ & $\begin{array}{c}\text { Share of } \\
\text { productivity gains } \\
(2)\end{array}$ & $\begin{array}{c}\text { Share of job } \\
\text { transitions } \\
(3)\end{array}$ & $\begin{array}{l}\text { Gains-to- } \\
\text { transitions } \\
\text { ratio } \\
(4)\end{array}$ \\
\hline \multicolumn{5}{|c|}{ Panel A: By age } \\
\hline Less than 25 & 0.28 & $12.9 \%$ & $17.9 \%$ & 0.72 \\
\hline Age $25-34$ & 1.01 & $46.5 \%$ & $34.8 \%$ & 1.34 \\
\hline Age $35-44$ & 0.55 & $25.3 \%$ & $25.2 \%$ & 1.00 \\
\hline Age $45-54$ & 0.27 & $12.5 \%$ & $15.8 \%$ & 0.79 \\
\hline Age 55 or older & 0.06 & $2.9 \%$ & $6.3 \%$ & 0.46 \\
\hline Total & 2.17 & & & \\
\hline \multicolumn{5}{|c|}{ Panel B: By worker skill quintile } \\
\hline Low Skill & 0.12 & $5.7 \%$ & $14.9 \%$ & 0.39 \\
\hline Q2 & 0.31 & $14.3 \%$ & $24.4 \%$ & 0.59 \\
\hline Q3 & 0.37 & $17.2 \%$ & $22.6 \%$ & 0.76 \\
\hline Q4 & 0.55 & $25.6 \%$ & $21.8 \%$ & 1.17 \\
\hline High Skill & 0.81 & $37.2 \%$ & $16.3 \%$ & 2.28 \\
\hline Total & 2.17 & & & \\
\hline \multicolumn{5}{|c|}{ Panel C: By gender } \\
\hline Male & 1.94 & $89.3 \%$ & $82.6 \%$ & 1.08 \\
\hline Female & 0.23 & $10.7 \%$ & $17.4 \%$ & 0.61 \\
\hline Total & 2.17 & & & \\
\hline \multicolumn{5}{|c|}{ Panel D: By job tenures (turnover propensity) } \\
\hline Short job tenure & 0.18 & $8.3 \%$ & $30.3 \%$ & 0.27 \\
\hline Q2 & 0.29 & $13.5 \%$ & $32.3 \%$ & 0.42 \\
\hline Q3 & 0.52 & $24.1 \%$ & $22.9 \%$ & 1.05 \\
\hline Q4 & 0.81 & $37.4 \%$ & $12.7 \%$ & 2.96 \\
\hline Long job tenure & 0.36 & $16.7 \%$ & $1.9 \%$ & 8.70 \\
\hline Total & 2.17 & & & \\
\hline
\end{tabular}

Note: Firm productivity is defined as the marginal product of labor using the production function estimates obtained following the methodology in Ackerberg et al. (2015) and using the wage bill as the measure of labor. Weighted average productivity gains are the adjusted average productivity gap in a group's worker transitions weighted by that group's share of total transitions.

Source: Authors' calculations based on Chilean SII data. 


\section{Appendix A.2}

\section{Exercises by Economic Sectors}

Table 9: Job Transitions and Productivity Gaps in Manufacturing

\begin{tabular}{|c|c|c|c|c|c|c|}
\hline & $\begin{array}{c}\text { Average } \\
\text { Productivity } \\
\text { Gap } \\
(1)\end{array}$ & $\begin{array}{l}\mathrm{p} 25 \\
(2)\end{array}$ & $\begin{array}{l}\mathrm{p} 50 \\
(3)\end{array}$ & $\begin{array}{l}\text { p75 } \\
(4)\end{array}$ & $\begin{array}{c}\text { Share } \\
\text { Upward } \\
\text { Trans. } \\
(5)\end{array}$ & $\begin{array}{c}\text { Transi- } \\
\text { tions } \\
(6)\end{array}$ \\
\hline \multicolumn{7}{|c|}{ Panel A: Labor Productivity } \\
\hline All & 9.7 & -58.6 & 4.8 & 74.2 & 52.1 & 414,336 \\
\hline Job-to-job & 18.4 & -51.7 & 8.5 & 82.1 & 53.6 & 171,841 \\
\hline Job-N-job & 3.6 & -63.6 & 2.4 & 69.5 & 51.0 & 242,495 \\
\hline \multicolumn{7}{|c|}{ Panel B: Adjusted Labor Productivity } \\
\hline All & 8.4 & -59.9 & 3.5 & 72.8 & 51.6 & 414,336 \\
\hline Job-to-job & 18.2 & -51.9 & 8.3 & 81.9 & 53.6 & 171,841 \\
\hline Job-N-job & 1.5 & -65.6 & 0.4 & 67.3 & 50.2 & 242,495 \\
\hline
\end{tabular}

Note: Productivity measured as log average labor productivity. Productivity gaps are defined as the difference between the firm of destination and the firm of origin for any given job transition. Values multiplied by 100 for readability. "Upward transitions" are defined as job transitions with a positive productivity gap.

Source: Authors' calculations based on Chilean SII data. 
Table 10: Job Transitions and Productivity Gaps in Retail

\begin{tabular}{|c|c|c|c|c|c|c|}
\hline & $\begin{array}{c}\text { Average } \\
\text { Productivity } \\
\text { Gap } \\
(1)\end{array}$ & $\begin{array}{l}\mathrm{p} 25 \\
(2)\end{array}$ & $\begin{array}{l}\mathrm{p} 50 \\
(3)\end{array}$ & $\begin{array}{l}\text { p75 } \\
(4) \\
\end{array}$ & $\begin{array}{c}\text { Share } \\
\text { Upward } \\
\text { Trans. } \\
(5)\end{array}$ & $\begin{array}{c}\text { Transi- } \\
\text { tions } \\
(6)\end{array}$ \\
\hline \multicolumn{7}{|c|}{ Panel A: Labor Productivity } \\
\hline All & 6.3 & -60.2 & 4.3 & 71.7 & 52.1 & 722,261 \\
\hline Job-to-job & 7.5 & -52.5 & 5.2 & 69.2 & 52.8 & 277,274 \\
\hline Job-N-job & 5.6 & -64.7 & 3.7 & 73.1 & 51.7 & 444,987 \\
\hline \multicolumn{7}{|c|}{ Panel B: Adjusted Labor Productivity } \\
\hline All & 4.4 & -62.1 & 2.6 & 69.7 & 51.3 & 722,261 \\
\hline Job-to-job & 7.2 & -52.8 & 4.9 & 68.9 & 52.6 & 277,274 \\
\hline Job-N-job & 2.7 & -67.6 & 1.1 & 70.2 & 50.5 & 444,987 \\
\hline
\end{tabular}

Note: Productivity measured as log average labor productivity. Productivity gaps are defined as the difference between the firm of destination and the firm of origin for any given job transition. Values multiplied by 100 for readability. "Upward transitions" are defined as job transitions with a positive productivity gap.

Source: Authors' calculations based on Chilean SII data.

Table 11: Job Transitions and Productivity Gaps in Services

\begin{tabular}{|c|c|c|c|c|c|c|}
\hline & $\begin{array}{c}\text { Average } \\
\text { Productivity } \\
\text { Gap } \\
(1)\end{array}$ & $\begin{array}{l}\mathrm{p} 25 \\
(2) \\
\end{array}$ & $\begin{array}{l}\mathrm{p} 50 \\
(3)\end{array}$ & $\begin{array}{l}\text { p75 } \\
(4) \\
\end{array}$ & $\begin{array}{c}\text { Share } \\
\text { Upward } \\
\text { Trans. } \\
(5)\end{array}$ & $\begin{array}{c}\text { Transi- } \\
\text { tions } \\
(6)\end{array}$ \\
\hline \multicolumn{7}{|c|}{ Panel A: Labor Productivity } \\
\hline All & 14.4 & -45.9 & 7.3 & 71.3 & 54.3 & $1,262,070$ \\
\hline Job-to-job & 23.4 & -36.7 & 9.7 & 75.4 & 56.1 & 607,735 \\
\hline Job-N-job & 6.1 & -55.5 & 4.8 & 67.9 & 52.7 & 654,335 \\
\hline \multicolumn{7}{|c|}{ Panel B: Adjusted Labor Productivity } \\
\hline All & 10.9 & -48.0 & 5.3 & 67.6 & 53.2 & $1,262,070$ \\
\hline Job-to-job & 19.3 & -38.4 & 8.8 & 71.9 & 55.5 & 607,735 \\
\hline Job-N-job & 3.1 & -57.7 & 2.0 & 63.7 & 51.1 & 654,335 \\
\hline
\end{tabular}

Note: Productivity measured as log average labor productivity. Productivity gaps are defined as the difference between the firm of destination and the firm of origin for any given job transition. Values multiplied by 100 for readability. "Upward transitions" are defined as job transitions with a positive productivity gap.

Source: Authors' calculations based on Chilean SII data. 
Figure 7: Conditional probability of moving to a more productive firm in Manufacturing

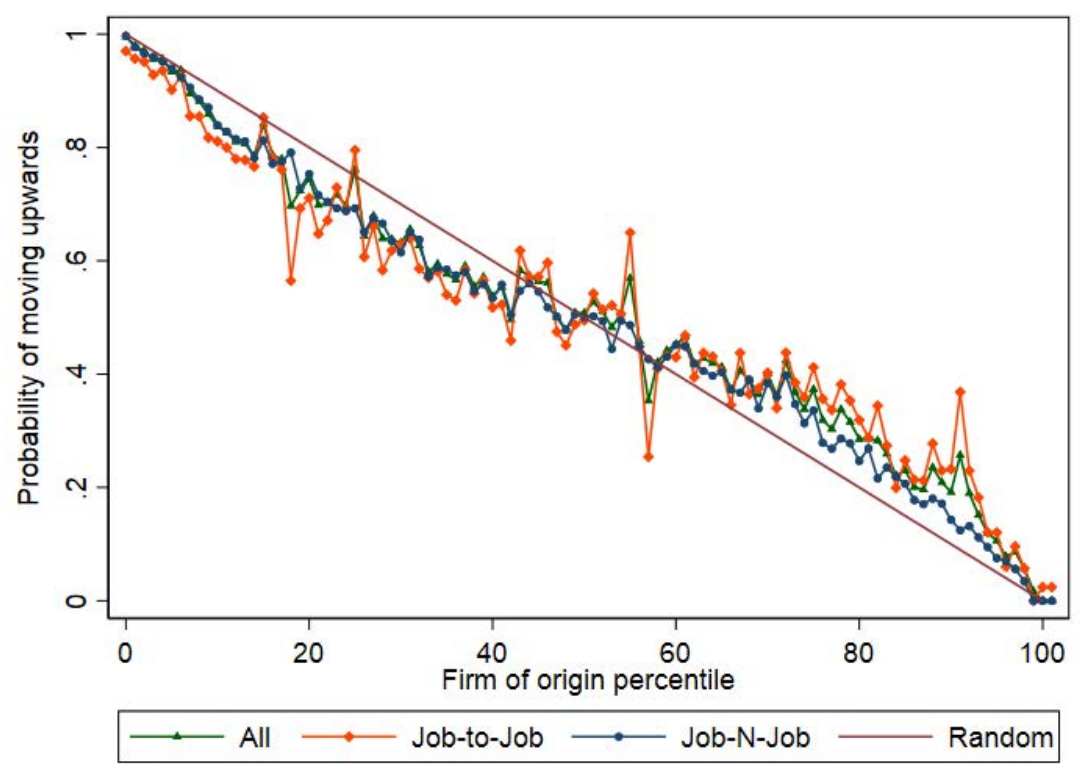

Note: Job transitions are sorted by adjusted labor productivity of the firm of origin. For each percentile of this distribution, the figure plots the share of transitions to a more productive firm.

Source: Authors' calculations based on Chilean SII data.

Figure 8: Conditional probability of moving to a more productive firm in Retail

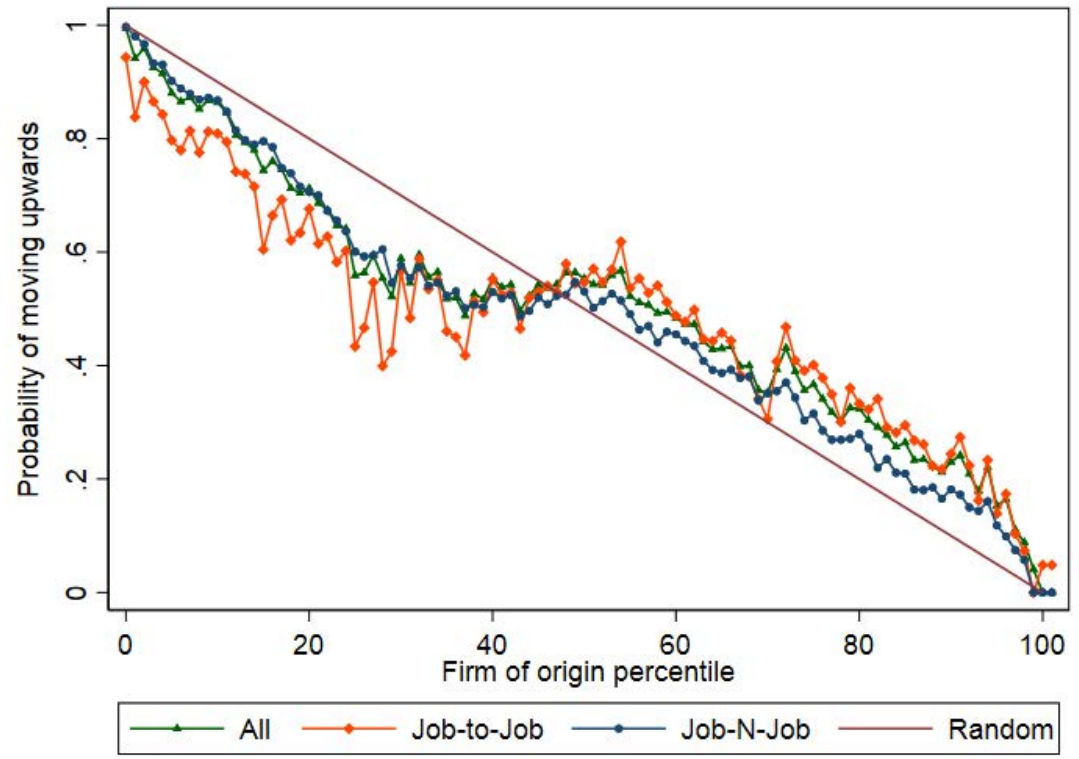

Note: Job transitions are sorted by adjusted labor productivity of the firm of origin. For each percentile of this distribution, the figure plots the share of transitions to a more productive firm.

Source: Authors' calculations based on Chilean SII data. 
Figure 9: Conditional probability of moving to a more productive firm in Services

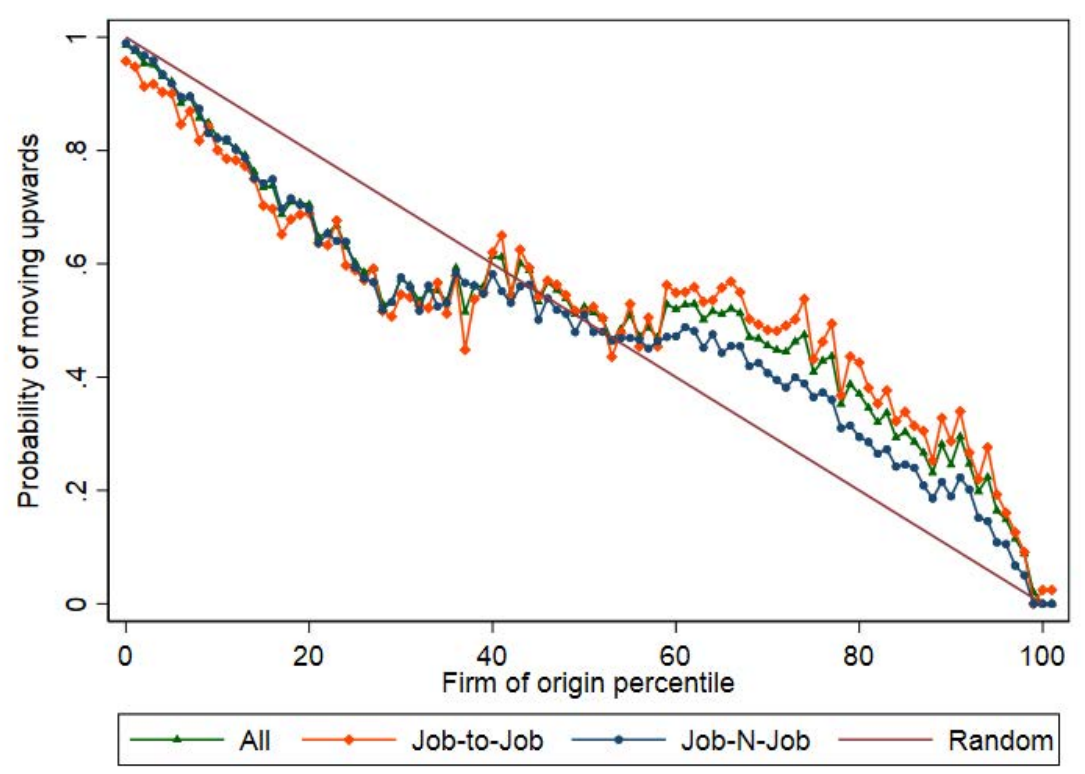

Note: Job transitions are sorted by adjusted labor productivity of the firm of origin. For each percentile of this distribution, the figure plots the share of transitions to a more productive firm.

Source: Authors' calculations based on Chilean SII data. 


\section{Appendix A.3}

\subsection{Productivity Gaps using the lagged productivity of the origin firm and the future productivity of the destination firm}

Table 12: Job Transitions and Productivity Gaps

\begin{tabular}{|c|c|c|c|c|c|c|}
\hline & $\begin{array}{c}\text { Average } \\
\text { Productivity } \\
\text { Gap } \\
(1)\end{array}$ & $\begin{array}{l}\mathrm{p} 25 \\
(2) \\
\end{array}$ & $\begin{array}{l}\mathrm{p} 50 \\
(3) \\
\end{array}$ & $\begin{array}{l}\text { p75 } \\
(4) \\
\end{array}$ & $\begin{array}{c}\text { Share } \\
\text { Upward } \\
\text { Trans. } \\
(5)\end{array}$ & $\begin{array}{c}\text { Transi- } \\
\text { tions } \\
(6) \\
\end{array}$ \\
\hline \multicolumn{7}{|c|}{ Panel A: Labor Productivity } \\
\hline All & 8.82 & -63.42 & 5.46 & 78.83 & 52.43 & $10,623,633$ \\
\hline Job-to-job & 18.42 & -51.37 & 9.66 & 83.14 & 54.68 & $4,174,762$ \\
\hline Job-N-job & 2.61 & -71.53 & 2.33 & 76.28 & 50.97 & $6,448,871$ \\
\hline \multicolumn{7}{|c|}{ Panel B: Adjusted Labor Productivity } \\
\hline All & 6.61 & -63.80 & 3.79 & 74.91 & 51.70 & $10,623,633$ \\
\hline Job-to-job & 16.77 & -51.48 & 9.19 & 80.54 & 54.40 & $4,174,762$ \\
\hline Job-N-job & 0.02 & -72.02 & -0.10 & 71.51 & 49.96 & $6,448,871$ \\
\hline \multicolumn{7}{|c|}{ Panel $C$ : Productivity Gap using productivities in $t-1$ and $t+1$} \\
\hline All & 2.81 & -66.68 & 0.81 & 69.98 & 50.39 & $8,055,878$ \\
\hline Job-to-job & 13.91 & -53.23 & 6.80 & 76.12 & 53.43 & $3,292,922$ \\
\hline Job-N-job & -4.87 & -76.34 & -4.05 & 65.90 & 48.28 & $4,762,956$ \\
\hline
\end{tabular}

Note: Panel C defines the gap using the productivity of the firm of origin the year prior to separation, and the productivity of the destination firm the year after the match. Productivity measured as log average labor productivity. Productivity gaps are defined as the difference between the firm of destination and the firm of origin for any given job transition. Values multiplied by 100 for readability. "Upward transitions" are defined as job transitions with a positive productivity gap.

Source: Authors' calculations based on Chilean SII data. 
Figure 10: Conditional probability of moving to a more productive firm

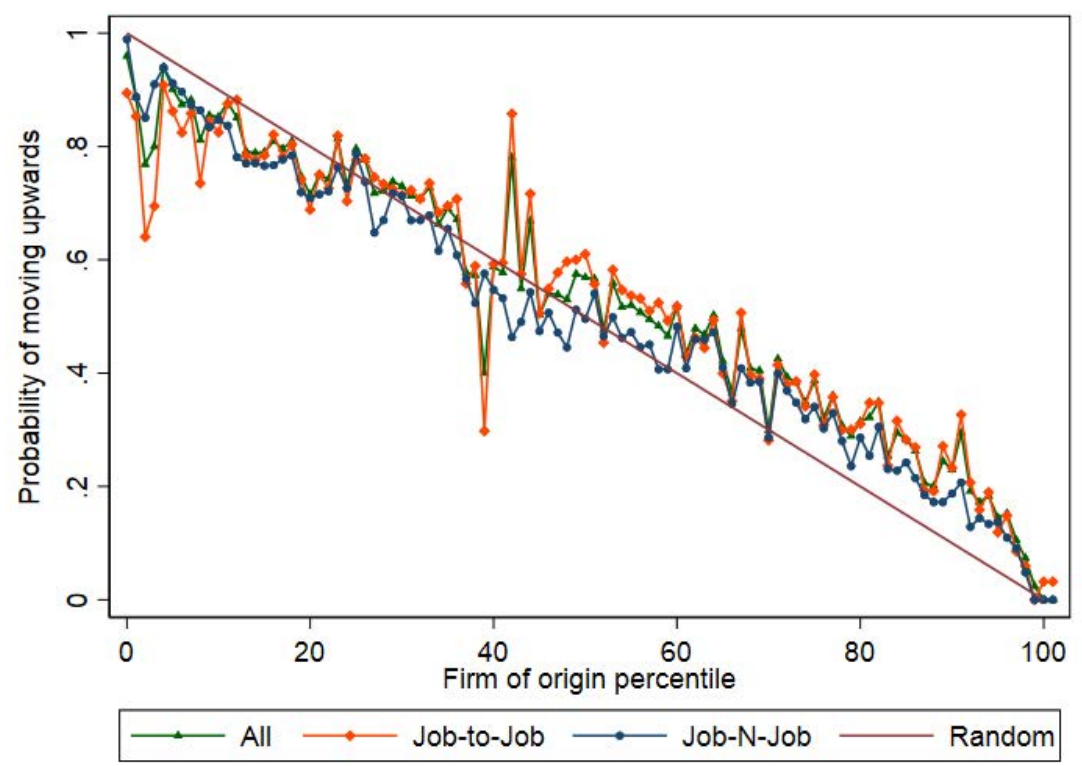

Note: Job transitions are sorted by adjusted labor productivity of the firm of origin, the year prior to the separation. For each percentile of this distribution, the figure plots the share of transitions to a more productive firm, with productivities at the destination firm calculated one year after the match. Source: Authors' calculations based on Chilean SII data. 